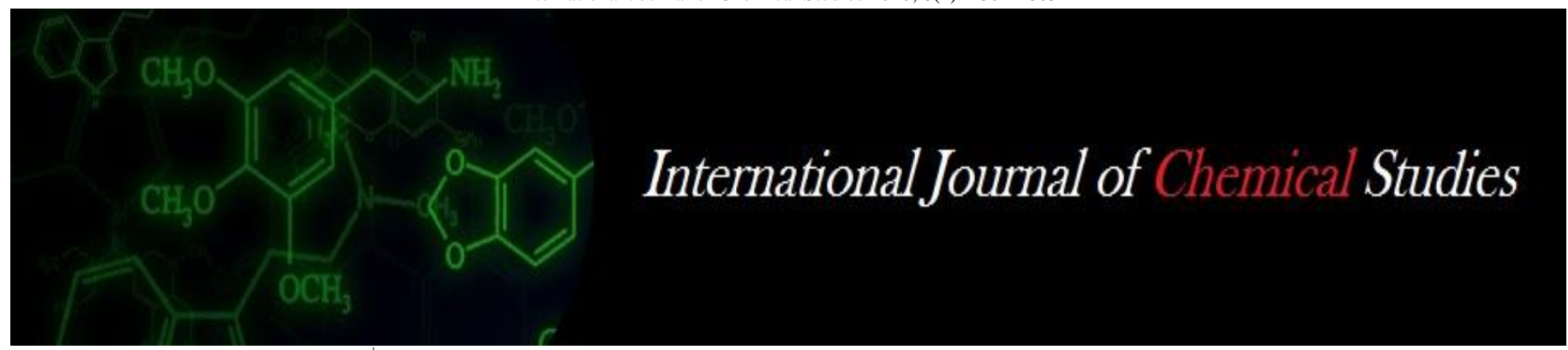

P-ISSN: 2349-8528

E-ISSN: 2321-4902

IJCS 2020; 8(1): 1861-1865

(C) 2020 IJCS

Received: 22-11-2019

Accepted: 24-12-2019

Suryakanta Kashyap

Department of Agronomy, G.B.

Pant University of Agriculture \&

Technology, Pantnagar,

Uttarakhand, India

\section{VP Singh}

Department of Agronomy, G.B. Pant University of Agriculture \& Technology, Pantnagar,

Uttarakhand, India

\section{SK Guru}

Department of Plant Physiology, G. B. Pant University of Agriculture \& Technology,

Pantnagar, Uttarakhand, India

Tej Pratap

Department of Agronomy, G.B.

Pant University of Agriculture \&

Technology, Pantnagar,

Uttarakhand, India

SP Singh

Department of Agronomy, G.B.

Pant University of Agriculture \&

Technology, Pantnagar,

Uttarakhand, India

Praveen BR

Agronomy Section, NDRI,

Karnal, Haryana, India

\section{Corresponding Author:} Suryakanta Kashyap

Department of Agronomy, G.B.

Pant University of Agriculture \&

Technology, Pantnagar,

Uttarakhand, India

\section{Effect of different integrated weed management practices on yield and economics of dry direct seeded rice}

\author{
Suryakanta Kashyap, VP Singh, SK Guru, Tej Pratap, SP Singh and \\ Praveen BR
}

DOI: https://doi.org/10.22271/chemi.2020.v8.i1aa.8535

\begin{abstract}
A field experiment was conducted during 2017-2018 at N. E. Borlaug Crop Research Centre of Govind Ballabh Pant University of Agriculture and Technology, Pantnagar, to study effect of different integrated weed management practices on yield and economics of dry direct seeded rice in tarai region. Higher grain yield, biological yield, harvest index characters were recorded under pre emergence application of pendimethalin $f b$ penoxsulam (PoE) $f b 1 \mathrm{HW} 45 \mathrm{DAS}$ at $25 \mathrm{~cm}$ spacing which was statistically at par with stale seed bed with shallow tillage $f b$ application of pre-emergence application of pendimethalin $f b 1$ mechanical weeding (MW) with conoweeder at 25 DAS along with $1 \mathrm{HW}$ at 45 DAS, mulch $\mathrm{fb}$ penoxsulam (PoE) $f b$ 1HW at 45 DAS, Sesbania line sowing with pre-emergence application of Pendimethalin $f b 1$ mechanical weeding $f b$ 1HW at 45 DAS and stale seed bed with shallow tillage $f b$ Sesbania line sowing $f b$ pre-emergence pendimethalin $f b$ brown manuring with 2,4-D at $500 \mathrm{~g} / \mathrm{ha} f b 1 \mathrm{HW}$ at 45 DAS. Whereas, benefit cost ratio was found higher (2.1) under pre emergence application of pendimethalin $f b$ penoxsulam $(\mathrm{PoE}) f b 1 \mathrm{HW} 45 \mathrm{DAS}$ at $25 \mathrm{~cm}$ spacing which was statistically at par with stale seed bed with shallow tillage $f b$ application of pre-emergence application of pendimethalin $f b 1$ mechanical weeding (MW) with conoweeder at 25 DAS along with $1 \mathrm{HW}$ at 45 DAS, mulch $\mathrm{fb}$ penoxsulam (PoE) $f b$ 1HW at 45 DAS and Sesbania line sowing with pre-emergence application of pendimethalin $f b 1$ mechanical weeding $f b 1 \mathrm{HW}$ at 45 DAS. From the study it can be concluded that above three integrated practices were same effective as recommended practice for controlling weed with higher return.
\end{abstract}

Keywords: Direct seeded rice, stalebed, penoxsulam, brownmanuring

\section{Introduction}

Rice (Oryza sativa L.) is being a major cereal and staple food grain crop of about more than half of the world's population. Direct seeding of rice requiring less water, labour and energy inputs is an alternative to puddling and transplanting. The direct-seeded rice matures earlier (710 days) than that of transplanted rice, thus allowing timely sowing of the succeeding crop. Weeds are the foremost limitation to the success of DSR in general and specifically to dryDSR (Rao et al., 2007) ${ }^{[12]}$. Due to greater variability in the growth habit of different weeds a single method of weed control cannot offer effective and season-long control in DSR which will also resulted inless grain yield and more cost of cultivation (Aulakh et al., 2013) ${ }^{[1]}$. So integration of chemical method of weed control along with other physica, cultural and biological option are found to be more effective under dry direct seeded rice for controlling weed and enhancing yield with less cost of cultivation and higher benefit cost ratio. Intercropping of brown manuring crops with rice reduced weed densities by about 40-50\% (Mahajan et al., 2012) ${ }^{[9]}$. In addition to brown manuring, stale seed bed technique can be integrate in weed control in direct seeded rice. So there is need to integrate other weed management strategies along with chemical control (Chahal et al., 2014, 2015) ${ }^{[3,4]}$. It has be found that herbicides in combination with other methods of weed control like physical and cultural result considerably superior weed control and better grain yield than the sole application due to their broad spectrum and long lasting weed control (Bhurer et al., 2013) ${ }^{[2]}$. 


\section{Material and Method}

A field experiment was conducted at Norman E. Borlaug Crop Research Center of G.B. Pant University of Agriculture and Technology Pantnagar, District of Udham Singh Nagar (Uttarakhand) during 'kharif' season of 2017-2018. This centre is situated at an altitude of 243.84 metres above mean sea level, $29^{\circ} \mathrm{N}$ latitude and $79.3^{\circ} \mathrm{E}$ longitudes lies at the foot hills of "Shivalik" ranges of Himalaya, a narrow belt called "Tarai" where the climate is subtropical. The soil of the experimental site is clay loam texture,

The experiment was laid out in randomized block design with twelve treatments $\left(\mathrm{T}_{1}\right.$-stale seed bed with shallow tillage followed by post emergence application of penoxsulam (PoE) at $22.5 \mathrm{~g} / \mathrm{ha}, \mathrm{T}_{2}$-stale seed bed with shallow tillage followed by pre emergence application of pendimethalin (PE) at $1000 \mathrm{~g} / \mathrm{ha}$ along with 1 hand weeding (HW) 30DAS, T $_{3}$-stale seed bed with shallow tillage followed by pre-emergence application of pendimethalin followed by 1 mechanical weeding (MW) with conoweeder at $25 \mathrm{DAS}$ along with $1 \mathrm{HW}$ at $45 \mathrm{DAS}, \mathrm{T}_{4}$-mulch (wheat straw of $4 \mathrm{t} / \mathrm{ha}$ ) followed by post emergence application of penoxsulam at $22.5 \mathrm{~g} / \mathrm{ha}$ followed by $1 \mathrm{HW}$ at 45 DAS, $\mathrm{T}_{5}$-post emergence application of penoxsulam at $22.5 \mathrm{~g} / \mathrm{ha}$ followed by $1 \mathrm{HW}$ at $45 \mathrm{DAS}, \mathrm{T}_{6}$-Sesbania line sowing with pre-emergence application of pendimethalin followed by 1 mechanical weeding 1t 25 DAS followed by $1 \mathrm{HW}$ at 45 DAS, $\mathrm{T}_{7}$-Sesbania broadcasting followed by brown manuring with 2,4-D at $500 \mathrm{~g} / \mathrm{ha}$ along with $1 \mathrm{HW}$ at 45 DAS, $\mathrm{T}_{8}$-stale seed bed with shallow tillage followed by Sesbania line sowing followed by pre-emergence pendimethalin followed by brown manuring with 2,4-D at 500 $\mathrm{g} / \mathrm{ha}$ followed by $1 \mathrm{HW}$ at $45 \mathrm{DAS}$, T9-pre emergence application of pendimethalin followed by penoxsulam (PoE) followed by $1 \mathrm{HW} 45 \mathrm{DAS}, \mathrm{T}_{10}$ - pre-emergence application of pendimethalin followed by penoxsulam (PoE) followed by 1HW 45 DAS $(20 \mathrm{~cm}), \mathrm{T}_{11}$-weedy check and $\mathrm{T}_{12}$-weedy free) which were replicated thrice. All the treatments were in $25 \mathrm{~cm}$ except one.

After harvesting of wheat, the field was prepared by two harrowing and levelling and after that 5-6 cm depth of irrigation was provided in the field. About 2 irrigations was provided in the field which allowed the weed seed to germinate. At $12^{\text {th }}$ days germinated weed seedlings were ploughed by shallow tillage by power tiller. Rice seeds of 'Govind' variety was sown on 13th june, 2017 in lines at seed rate of $40 \mathrm{~kg} / \mathrm{ha}$ with a spacing of $25 \mathrm{~cm}$ apart manually in all plots and in one treatment $\left(\mathrm{T}_{10}\right)$ recommended row to row spacing of $20 \mathrm{~cm}$ was maintained. For brown manuring, seeds of Sesbania were alternatively grown with rice at the seed rate of $40 \mathrm{~kg} / \mathrm{ha}$. And in case of broadcasting, seeds were broadcasted before sowing of rice on the same day. Crop was fertilized with 120: 60:40 kg/ha of $\mathrm{N}, \mathrm{P}_{2} \mathrm{O}_{5}, \mathrm{~K}_{2} \mathrm{O}$, respectively in the experimental area. Grain yield is calculated from the harvested grain under net plot area from each plot expressed as tons per hectare. The weight of total produce (biological yield) per net plot was weighed before threshing. The straw yield was calculated by subtracting grain yield from biological yield and expressed as tons per hectare. The weight of the grain and straw will be taken separately and Grain: straw ratio will be calculated as under:

Grain: straw ratio $=\frac{\text { Weight of grain }}{\text { Weight of the straw }}$

Harvest index was calculated by using following formula and expressed in \%

Harvest index $=\frac{\text { Economic yield }}{\text { Biological yield }} \times 100$

\section{Economics}

Common cost of production was calculated and the additional weed management treatment was calculated. Benefit cost ratio was calculated to assess the economics of rice due to various integrated weed management treatment.

\section{Result and Discussion \\ Number of panicles (No./m²)}

Different weed management methods have significant impact on number of panicles $/ \mathrm{m}^{2}$ (Table.1). All other treatments recorded significantly higher number of panicles $/ \mathrm{m}^{2}$ over weedy check. Weedy check treatment resulted lowest number of panicles $/ \mathrm{m}^{2}$ at all stages. Recommended practice with wider spacing $\left(\mathrm{T}_{9}\right)$ resulted significantly higher panicles $/ \mathrm{m}^{2}$ than recommended practice narrower spacing $\left(\mathrm{T}_{10}\right)$. This might be due to the fact that better development of early tillers up to reproductive phase of the crop while in case of closer seeding the production of tillers may take place but due to unavailability of sufficient amount of photosynthates due to higher plant density might have resulted lesser number of productive tillers. Similar result was also reported by Sultana et al., $2012^{[18]}$. Number of panicles significantly highest under weed free at all stages of crop growth, being at par with $\mathrm{T}_{9}, \mathrm{~T}_{3}, \mathrm{~T}_{4}, \mathrm{~T}_{6}$ and $\mathrm{T}_{8}$.

At recommended practice with wider spacing $\left(\mathrm{T}_{9}\right)$ resulted significantly higher panicle length, filled grains/panicle and total number of grains/panicles than recommended practice with narrower spacing spacing $\left(\mathrm{T}_{10}\right)$. This might be due to reduced inter- and intra-plant competition which ultimately favored development of heavy panicles and healthy and plump grains at wider spacing (Sihag et al., 2015) ${ }^{[15]}$.

Panicle length and number of filled grains/panicle under weed free condition was statistically at par with $\mathrm{T}_{3}, \mathrm{~T}_{5}, \mathrm{~T}_{6}, \mathrm{~T}_{8}$ and $\mathrm{T}_{9}$. This might be due to frequent elimination of weeds that resulted in the reduced weed competition, better nutrient availability, better growth and length of panicle and number of grains per panicle. This findings was in accordance with Viren et al., $2005^{[19]}$ and Gowda et al., $2009^{[6]}$.

Different weed management practices did not have any significant impact on test weight of grain. Highest weight of 1000 grains $(27.5 \mathrm{~g} / 1000$ seeds) was recorded in weed free which was statistically at par with remaining eleven treatments. This result was in accordance with Nadeem et al., $2011^{[10]}$ and Singh et al, 2006. 
Table 1: Effect of different weed management practices on yield attributes

\begin{tabular}{|c|c|c|c|c|c|c|c|}
\hline $\begin{array}{l}\text { S. } \\
\text { No. }\end{array}$ & Treatment & $\begin{array}{l}\text { Dose } \\
\text { (g/ha) }\end{array}$ & $\begin{array}{c}\text { Panicle } \\
(\text { No./m2) }\end{array}$ & $\begin{array}{c}\text { Panicle } \\
\text { length } \\
(\mathrm{cm})\end{array}$ & \begin{tabular}{|l|}
$\begin{array}{l}\text { Filled } \\
\text { grain/ } \\
\text { panicle }\end{array}$ \\
\end{tabular} & $\begin{array}{c}\text { Total } \\
\text { grain/ } \\
\text { Panicle }\end{array}$ & \begin{tabular}{|c|}
1000 \\
grain \\
weight $(\mathrm{g})$
\end{tabular} \\
\hline $\mathrm{T}_{1}$ & SSB $f b$ penoxsulam (PoE) & 22.5 & 174.7 & 27.0 & 68.0 & 98.0 & 26.3 \\
\hline $\mathrm{T}_{2}$ & SSB $f b$ pendimethalin (PE) $f b 1$ HW 30 DAS & 1000 & 182.0 & 27.1 & 73.3 & 98.0 & 26.5 \\
\hline $\mathrm{T}_{3}$ & SSB $f b$ Pendimethalin (PE) $f b 1 \mathrm{MW} f b$ 1HW 45 DAS & 1000 & 226.0 & 28.9 & 78.7 & 100.0 & 27.2 \\
\hline $\mathrm{T}_{4}$ & Mulch $f b$ penoxsulam (PoE) $f b$ 1HW 45 DAS & 22.5 & 214.7 & 28.8 & 78.3 & 107.3 & 27.2 \\
\hline $\mathrm{T}_{5}$ & Penoxsulam (PoE) $f b$ 1HW 45 DAS & 22.5 & 164.0 & 26.6 & 72.0 & 96.3 & 25.9 \\
\hline $\mathrm{T}_{6}$ & Sesbania (LS) + Pendimethalin (PE) $f b 1$ MW 25 DAS $f b$ 1HW 45 DAS & 1000 & 220.7 & 28.7 & 77.7 & 112.0 & 27.1 \\
\hline $\mathrm{T}_{7}$ & Sesbania (BC) brown manuring with 2,4-D $f b 1 \mathrm{HW} 45$ DAS & 500 & 156.0 & 26.0 & 72.7 & 94.7 & 25.7 \\
\hline $\mathrm{T}_{8}$ & $\begin{array}{l}\text { SSB } f b S e s b a n i a \text { (LS) } f b \text { pendimethalin (PE) } f b \text { 2,4-D (PoE) } 1 \text { HW } 45 \\
\text { DAS }\end{array}$ & $1000+500$ & 204.7 & 28.5 & 77.3 & 100.0 & 27.1 \\
\hline $\mathrm{T}_{9}$ & Pendimethalin (PE) $f b$ Penoxsulam (PoE) $f b 1$ HW 45 DAS & $1000+22.5$ & 219.3 & 28.9 & 79.3 & 110.3 & 27.3 \\
\hline $\mathrm{T}_{10}$ & Pendimethalin (PE) $f b$ Penoxsulam (PoE) $f b 1 \mathrm{HW}(20 \mathrm{~cm}) 45$ DAS & $1000+22.5$ & 178.0 & 27.3 & 74.7 & 99.0 & 27.0 \\
\hline $\mathrm{T}_{11}$ & Weedy check & & 80.7 & 25.3 & 63.3 & 92.3 & 25.7 \\
\hline $\mathrm{T}_{12}$ & Weed free & & 223.3 & 28.9 & 80.0 & 106.0 & 27.5 \\
\hline & SEm \pm & & 7.65 & 0.41 & 1.13 & 0.96 & 0.51 \\
\hline & C.D. $(5 \%)$ & & 22.6 & 1.2 & 13.3 & 2.8 & NS \\
\hline
\end{tabular}

\section{Yield}

Highest grain yield (4.4 t/ha) was recorded (table 2 ) in the weed free condition which was statistically at par with the treatments; recommended practice with wider row spacing $\left(\mathrm{T}_{9}\right)$ stale seed bed followed by shallow tillage followed by pre-emergence application of pendimethalin at $1000 \mathrm{~g} / \mathrm{ha}$ followed by 1 mechanical weeding at 25 DAS with conoweeder along with $1 \mathrm{HW}$ at $45 \mathrm{DAS}\left(\mathrm{T}_{3}\right)$, mulching integrated with post-emergence application of penoxsulam at $22.5 \mathrm{~g} / \mathrm{ha}$ followed by $1 \mathrm{HW}$ at $45 \mathrm{DAS}\left(\mathrm{T}_{4}\right)$, line sown Sesbania integrated with pre-emergence application of pendimethalin at $1000 \mathrm{~g} / \mathrm{ha}$ followed by $1 \mathrm{MW}$ at $25 \mathrm{DAS}$ along with $1 \mathrm{HW}$ at $45 \mathrm{DAS}\left(\mathrm{T}_{6}\right)$ and stale seed bed followed by shallow tillage along with line sown Sesbania followed bypre-emergence application of pendimethalin at $1000 \mathrm{~g} / \mathrm{ha}$ followed by post-emergence application of 2,4-D at $500 \mathrm{~g} / \mathrm{ha}$ supplemented with $1 \mathrm{HW}$ at $45 \mathrm{DAS}\left(\mathrm{T}_{8}\right)$. This was due to lower weed biomass accumulation which results in higher weed control efficiency. Similar result were also suggested by Gaire et al., 2013 that Sesbania co-culture technology reduces the weed population by nearly about $50 \%$ with no adverse effect on rice yield as comprise of growing of of rice and sesbania together and then killing Sesbania with 2, 4-D as it provide smootering effect on weed and also use of 2,4-D effectively controls the broadleaf weeds. Also inclusion of mechanical weeding by conoweeder not only provided better weed control in inter rows but also also provided aeration in soil root zone resulting better root growth and tillering and finally the better crop yield (Kumar et al., 2012).

Biological yield were significantly influenced by different IWM practices. All the treatments resulted significantly higher straw yield as compared to weedy check.

Highest straw yield and biological yield were recorded in weed free $\left(T_{12}\right)$. This might be due to frequent elimination of weeds that resulted in the reduced weed competition, required particularly at most rapid tillering stage of rice (Mann et al., 2007 and Yadav et al., 2007) ${ }^{[13,20]}$. Also this treatment was being statistically at par with pre-emergence application of pendimethalin at $1000 \mathrm{~g} / \mathrm{ha} \mathrm{fb}$ post-emergence application of penoxsulam at $22.5 \mathrm{~g} / \mathrm{ha}$ supplemented with $1 \mathrm{HW}$ at $45 \mathrm{DAS}$ $\left(\mathrm{T}_{9}\right)$, pre-emergence application of pendimethalin at $1000 \mathrm{~g} / \mathrm{ha}$ $f b$ post-emergence application of penoxsulam at $22.5 \mathrm{~g} / \mathrm{ha}$ supplemented with $1 \mathrm{HW}$ at 45 DAS at $20 \mathrm{~cm}$ spacing $\left(\mathrm{T}_{10}\right)$, stale seed bed $f b$ shallow tillage integrated with Sesbania line sowing $f b$ pre-emergence application of pendimethalin at $1000 \mathrm{~g} / \mathrm{ha} f b$ 2,4-D supplemented with $1 \mathrm{HW} 45 \mathrm{DAS}\left(\mathrm{T}_{8}\right)$, line sown Sesbania with pre-emergence application of pendimethalin at $1000 \mathrm{~g} / \mathrm{ha} f b 1 \mathrm{MW}$ along with 1 HW 45 DAS $\left(\mathrm{T}_{6}\right)$, stale seed bed $f b$ shallow tillage $f b$ pre-emergence application of pendimethalin at $1000 \mathrm{~g} / \mathrm{ha} f b 1 \mathrm{MW}$ at 25DAS with conoweeder along with $1 \mathrm{HW} 45 \mathrm{DAS}\left(\mathrm{T}_{3}\right)$ and mulch integrated with post-emergence application of penoxsulam at $22.5 \mathrm{~g} / \mathrm{ha} 45 \mathrm{DAS}\left(\mathrm{T}_{4}\right)$. Lowest straw yield and biological yield was obtained in weedy check plot.

\section{Economics of different weed control treatments}

Economic analysis of various weed management practices including total cost of cultivation, gross return, net return and benefit cost ratio are summarized Table. 2. Due to differences in cost of weed control among treatments, the total cost of production also varied within the treatments. From economic analysis it was observed that the maximum cost involved in case of weed free treatment. Among the integrated methods maximum cost was involved in stale seed bed $f b$ shallow tillage with line sown Sesbania integrated with pre-emergence application of pendimethalin at $1000 \mathrm{~g} / \mathrm{ha} f b 2,4-\mathrm{D} 500 \mathrm{~g} / \mathrm{ha}$ supplemented with $1 \mathrm{HW}$ at $45 \mathrm{DAS}\left(\mathrm{T}_{8}\right)$.

Maximum gross return was found under both stale seed bed $f b$ shallow tillage $f b$ pre-emergence application of pendimethalin at $1000 \mathrm{~g} / \mathrm{ha} f b 1 \mathrm{MW}$ at $25 \mathrm{DAS}$ with conoweeder $f b 1 \mathrm{HW}$ at 45 DAS $\left(\mathrm{T}_{3}\right)$ followed by recommended practice at wider spacing $\left(\mathrm{T}_{9}\right)$, line sown Sesbania with pre-emergence application of pendimethalin at $1000 \mathrm{~g} / \mathrm{ha} \mathrm{fb} 1 \mathrm{MW}$ at $25 \mathrm{DAS}$ $f b 1 \mathrm{HW}$ at $45 \mathrm{DAS}\left(\mathrm{T}_{6}\right)$, mulch integrated with postemergence application of penoxsulam at $22.5 \mathrm{~g} / \mathrm{ha}\left(\mathrm{T}_{3}\right)$ and stale seed bed technique with line sown Sesbania $f b$ preemergence application of pendimethalin at $1000 \mathrm{~g} / \mathrm{ha} \mathrm{fb}$ postemergence application of 2,4-d at 500g/ha $f b 1 \mathrm{HW}$ at 45 DAS $\left(\mathrm{T}_{8}\right)$.

Highest net return was found under stale seed bed $f b$ shallow tillage $f b$ pre-emergence application of pendimethalin at $1000 \mathrm{~g} / \mathrm{ha} f b 1 \mathrm{MW}$ at 25DAS with conoweeder supplemented with $1 \mathrm{HW}$ at $45 \mathrm{DAS}\left(\mathrm{T}_{3}\right)$, while lowest net return was under post-emergence application of penoxsulam at $22.5 \mathrm{~g} / \mathrm{ha}$ along with $1 \mathrm{HW}$ at 45 DAS $\left(\mathrm{T}_{5}\right)$. This might be due lowest grain and straw yield that was obtained under this treatment. Benefit cost ratio was found highest (2.1) under recommended practice with wider spacing of $25 \mathrm{~cm}\left(\mathrm{~T}_{9}\right)$ which was similar with stale seed bed followed by shallow tillage followed by pre-emergence application of pendimethalin at $1000 \mathrm{~g} /$ ha followed by $1 \mathrm{MW}$ at $25 \mathrm{DAS}$ with conoweeder supplemented with $1 \mathrm{HW}$ at $45 \mathrm{DAS}\left(\mathrm{T}_{3}\right)$, 
mulch followed by post-emergence application of penoxsulam at $22.5 \mathrm{~g} / \mathrm{ha}$ along with $1 \mathrm{HW}$ at $45 \mathrm{DAS}\left(\mathrm{T}_{4}\right)$ and Sesbania line sowing with pre-emergence application of pendimethalin at $1000 \mathrm{~g} / \mathrm{ha}$ followed by $1 \mathrm{MW}$ at $25 \mathrm{DAS}$ along with $1 \mathrm{HW}$ at $45 \mathrm{DAS}\left(\mathrm{T}_{6}\right)$. This might be resulted due to lower cost of cultivation and higher grain yield which resulted higher return. Similar results were reported by Narolia et al. (2014) ${ }^{[11]}$ and Jayadeva et al. $(2011)^{[7]}$.

\section{Conclusion}

It can be concluded that pre emergence application of pendimethalin followed by post-emergence application of penoxsulam followed by 1 hand weeding (45 DAS) under $25 \mathrm{~cm}$ resulted higher yield attributing parameters, grain yield as compared to crop with same of weed control practice under $20 \mathrm{~cm}$ spacing. However satisfactory weed management and similar rice yield attributes and yields can be achieved by combination of stale seed bed technique integrated with preemergence application of pendimethalin herbicide along with mechanical weeding, pre-emergence application of pendimethalin herbicide with Sesbania brown manuring with mechanical weeding and hand weeding at 45 DAS and wheat straw mulch with PoE application of penoxsulam followed by 1 hand weeding at 45 DAS. All these IWM practices have similar benefit cost ratio. So, farmers can choose any of these IWM packages for weed management in dry DSR which suits them best.

Table 2: Effect of different weed management practices on grain yield ( $\mathrm{t} / \mathrm{ha})$, biological yield ( $\mathrm{t} / \mathrm{ha}$ ) and economics

\begin{tabular}{|c|c|c|c|c|c|c|c|c|}
\hline $\begin{array}{l}\text { S. } \\
\text { No. }\end{array}$ & Treatment & $\begin{array}{l}\text { Dose } \\
(\mathrm{g} / \mathrm{ha})\end{array}$ & $\begin{array}{l}\text { Grain yield } \\
(\mathrm{t} / \mathrm{ha})\end{array}$ & $\begin{array}{l}\text { Biological yield } \\
\text { (t/ha) }\end{array}$ & $\begin{array}{c}\text { Cost of } \\
\text { cultivation } \\
(\square / \mathrm{ha})\end{array}$ & $\begin{array}{l}\text { Gross } \\
\text { return } \\
\text { ( } \square / \mathrm{ha})\end{array}$ & $\begin{array}{c}\text { Net } \\
\text { return } \\
\text { ( } \square / \text { ha) }\end{array}$ & $\begin{array}{l}\text { B:C } \\
\text { ratio }\end{array}$ \\
\hline $\mathrm{T} 1$ & SSB $f b$ penoxsulam (PoE) & 22.5 & 3.5 & 8.2 & 26920 & 50350 & 23430 & 1.9 \\
\hline $\mathrm{T} 2$ & SSB $f b$ pendimethalin (PE) $f b 1$ HW 30 DAS & 1000 & 3.6 & 8.7 & 27760 & 51775 & 24015 & 1.9 \\
\hline T3 & SSB $f b$ Pendimethalin (PE) $f b 1 \mathrm{MW} f b$ 1HW 45 DAS & 1000 & 4.3 & 10.1 & 29080 & 61275 & 32195 & 2.1 \\
\hline T4 & Mulch $f b$ penoxsulam (PoE) $f b$ 1HW 45 DAS & 22.5 & 4.1 & 9.6 & 28040 & 58425 & 30385 & 2.1 \\
\hline T5 & Penoxsulam (PoE) $f b$ 1HW 45 DAS & 22.5 & 3.2 & 7.7 & 27020 & 46075 & 19055 & 1.7 \\
\hline T6 & $\begin{array}{c}\text { Sesbania (LS) + Pendimethalin (PE) } f b 1 \text { MW } 25 \text { DAS } f b \\
\text { 1HW 45 DAS }\end{array}$ & 1000 & 4.2 & 10.0 & 28240 & 59850 & 31610 & 2.1 \\
\hline $\mathrm{T} 7$ & $\begin{array}{c}\text { Sesbania (BC) brown manuring with 2,4-D } f b 1 \text { HW } 45 \\
\text { DAS }\end{array}$ & 500 & 3.2 & 8.3 & 26540 & 45125 & 18585 & 1.7 \\
\hline $\mathrm{T} 8$ & $\begin{array}{l}\text { SSB } f b S e s b a n i a \text { (LS) } f b \text { pendimethalin (PE) } f b \text { 2,4-D } \\
\text { (PoE) } 1 \text { HW 45 DAS }\end{array}$ & $\begin{array}{c}1000+ \\
500\end{array}$ & 4.0 & 9.6 & 29920 & 57475 & 27555 & 1.9 \\
\hline T9 & $\begin{array}{c}\text { Pendimethalin (PE) } f b \text { Penoxsulam (PoE) } f b 1 \mathrm{HW} 45 \\
\text { DAS }\end{array}$ & $\begin{array}{c}1000+ \\
22.5\end{array}$ & 4.2 & 9.9 & 28960 & 59850 & 30890 & 2.1 \\
\hline $\mathrm{T} 10$ & $\begin{array}{c}\text { Pendimethalin (PE) } f b \text { Penoxsulam (PoE) } f b 1 \mathrm{HW}(20 \mathrm{~cm}) \\
\text { 45 DAS }\end{array}$ & $\begin{array}{c}1000+ \\
22.5\end{array}$ & 3.7 & 9.4 & 28960 & 52725 & 23765 & 1.8 \\
\hline T11 & Weedy check & & 1.3 & 2.2 & 22840 & 18525 & -4315 & \begin{tabular}{|l|}
0.8 \\
\end{tabular} \\
\hline T12 & Weed free & & 4.4 & 6.0 & 34060 & 62225 & 28165 & 1.8 \\
\hline & SEm \pm & & 0.12 & 0.21 & & & & \\
\hline & C.D. (5\%) & & 0.4 & 0.6 & & & & \\
\hline
\end{tabular}

\section{References}

1. Aulakh JS. Integrated Palmer amaranth management in glufosinate-resistant cotton:II. Primary, secondary and conservation tillage. Indian Journal of Agronomy. 2013; $13: 28-42$.

2. Bhurer KP, Yadav DN, Ladha JK, Thapa RB, Pandey KR. Effect of integrated weed management practices on performance of dry direct seeded rice. Agonomy Journal of Nepal. 2013; 3:53-63.

3. Chahal PS, Jhala AJ. Herbicide programs for control of glyphosate - resistant volunteer corn in glufosinate resistant soybean. Weed Technol. 2015; 29(3):431-443.

4. Chahal PS. Efficacy of pre-emergence and postemergence soybean herbicides for control of glufosinate, glyphosate and imidazolinone-resistant volunteer corn. J. Agric. Sci. 2014; 6:131-140.

5. Gaire R, Dahal KR, Amgain LP. Effect of different mulching materials on weed dynamics and yield of direct seeded rice in Chitwan, Nepal. Agron J Nepal. 2013; 3:73-81.

6. Gowda PT, Shankaraiah C, Jnanesh AC, Govindappa M, Murthy KN. Studies on chemical weed control in aerobic rice (Oryza sativa L.). Journal of Crop and Weed. 2009; 5(1):321-324.

7. Jayadeva HM, Bhairappanavar ST, Hugar AY, Rangaswamy BR, Mallikarjun GB, Malleshappa C et al. 2011. Integrated weed management in aerobic rice
(Oryza sativa). Agriculture Science Digest. 2011; 31(1):58-61.

8. Kashyap S, Singh VP, Guru SK, Pratap T, Singh SP, Praharaj S. Integrated Weed Control Option for Dry Direct Seeded Rice under Irrigated Ecosystem Int. J Curr. Microbiol. App. Sci. 2019; 8(2):315-323.

9. Mahajan G, Chauhan BS, Timsina J, Singh PP. Crop performance and water and nitrogen- use efficiencies in dry-seeded rice in response to irrigation and fertilizer amounts in northwest India. Field Crops Res. 2012; 134:59-70.

10. Nadeem A, Ehsanullah KJ, Muhammad AA. Weed management improves yield and quality of direct seeded rice. Australian Journal of Crop Science. 2011; 5(6):688694.

11. Narolia RS, Singh P, Prakash C, Heena F. Effect of irrigation schedule and weed management practices on productivity and profitability of direct-seeded rice (Oryza sativa) in South-eastern Rajasthan. Indian Journal of Agronomy. 2014; 59(3):398-403.

12. Rao AN, Johnson DE, Sivaprasad B, Ladha JK, Mortimer AM. Weed management in direct-seeded rice. Adv Agron. 2007; 93:153-255.

13. Mann RA, Ahmad S, Hassan G, Baloch MS. Weed management in direct seeded rice crop. Pakistan J Weed Sci Res. 2007; 13(3-4):219-26.

14. Seema Pandey PC, Singh DK, Thoithoi M. Effect of weed management practices along with brown manuring 
on yield of aerobic rice and weed control efficiency at different nitrogen levels. Environment and Ecology. 2015; 33(2A):819-822.

15. Sihag SK, Singh MK, Meena RS. Naga SR. Bahadur S. Gaurav Yadav SR. Influences of spacing on growth and yield potential of dry direct seeded rice (Oryza sativa L.) culitavrs. The ecosan. 2015; 9(1-2):517-519.

16. Singh VP, Singh G, Singh SP, Kumar A, Singh Y, Johnson DE et al. Effect of rice wheat establishment methods and weed management in irrigated rice-wheat production system. 200. In Workshop on Direct Seeded Rice in the Rice-wheat System of the IGP, 1 February to 2 February, G.B. Pant University of Agriculture \&Technology, Pantnagar, U.S. Nagar, Uttaranchal, India, 2005, 12.

17. Singh VP, Singh RP, Singh Y. Integrated weed management in direct dry seeded rainfed lowland rice. Indian Journal of Weed Science. 2005; 38(1-2):49-53.

18. Sultana MR, Rahman MM, Rahman MH. Effect of row and hill spacing on the yield performance of boro rice (cv. BRRI dhan45) under aerobic system of cultivation. Journal of the Bangladesh Agricultural University. 2012; 10(1):39-42.

19. Viren M, Verma V, Dave AK. Efficacy of different weed control treatment in direct seeded rainfed rice. Oryza, 2005; 42(3):197-200.

20. Yadav S, Gill MS, Kukal SS. Performance of directseeded basmati rice in loamy sand in semi-arid subtropical India. Soil Till. Rese. 2007; 97:229-238.

21. Walia US, Bhullar MS, Nayyar S, Walia SS. Control of complex weedflora of dry seeded rice (Oryza sativa L.) with pre and post emergence herbicides. Indian $\mathrm{J}$ Weed Sci. 2008; 40(3-4):161-64. 